\title{
Analisis Produktivitas Maksimum Penggunaan Lahan di Jalan Raya Meruyung Kota Depok
}

\author{
Siti Nur Sarah Mayangsari dan Christiono Utomo \\ Jurusan Teknik Sipil, Fakultas Teknik Sipil dan Perencanaan, Institut Teknologi Sepuluh Nopember \\ Jl. Arief Rahman Hakim, Surabaya 60111 \\ e-mail: sarah.mayangsari@gmail.com,christiono@ce.its.ac.id
}

\begin{abstract}
Abstrak-Seiring dengan perkembangan kota Depok, dapat dijumpai beberapa lahan di kawasan kota yang tidak terdapat aktivitas diatasnya yang disebabkan oleh beberapa faktor belum munculnya aktivitas baru pada lahan yang ditinggalkan oleh aktivitas sebelumnya atau tidak berkem-bangnya aktivitas yang pernah ada sebelumnya. Salah satu lahan yang kurang termanfaatkan dengan optimal adalah lahan di Jalan Raya Meruyung. Saat ini lahan masih dalam keadaan kosong tanpa ada aktivitas diatasnya. Lahan seluas $14376 \mathrm{~m}^{2}$ ini terletak di daerah meruyung, Kota depok dan berada pada kawasan komersial yang cocok untuk dikembangkan menjadi properti komersial seperti hotel, perkantoran, ruko dan perumahan. Berdasarkan hal ini, maka perlu dilakukan penelitian untuk menetapkan produktivitas maksimum penggunaan lahan di Jalan Raya Meruyung Kota Depok tersebut

Analisis lahan di Jalan Raya Meruyung Kota Depok menggunakan prinsip dasar penilaian dengan metode Highest and Best Use (HBU). Analisis ini meliputi empat hal pokok yaitu, analisis kelayakan secara fisik, analisis kelayakan secara peraturan, analisis kelayakan secara keuangan, dan analisis produktivitas yang maksimal.

Hasil penelitian ini didapatkan alternatif perkantoran sebagai alternatif terbaik dengan nilai lahan tertinggi sebesar Rp. 11,571,574 dengan produktivitas maksimum sebesar $136 \%$.
\end{abstract}

Kata Kunci-HBU, Jalan Raya Meruyung, Lahan, Produktivitas.

\section{PENDAHULUAN}

$\mathrm{P}$ ERKEMBANGAN kota akan terus terjadi sejalan dengan perkembangan jumlah penduduk dan kegiatan sosial ekonomi penduduk yang menyertainya. Pertumbuhan penduduk mengakibatkan meningkatnya permintaan ketersediaan lahan yang dipergunakan untuk menyelenggarakan kegiatan. Ketersediaan lahan yang terbatas akan menimbulkan persaingan di antara pengguna lahan kota. Hal ini sesuai dengan prinsip ekonomi, bahwa pengguna selalu akan memaksimalkan penggunaan lahannya. Usaha-usaha untuk memaksimalkan penggunaan lahan tercermin dari semakin intensifnya pemanfaatan suatu guna lahan. Kegiatan-kegiatan yang dianggap tidak produktif dan tidak menguntungkan selalu akan dengan cepat digantikan dengan kegiatan lain yang lebih produktif dan menguntungkan (khususnya secara ekonomi). Persaingan terjadi untuk pemanfaatan yang paling menguntungkan sehingga dapat mendorong terjadinya perubahan pemanfaatan lahan (Prasetya, 2013) [1].

Seiring dengan perkembangan kota Depok, dapat dijumpai beberapa lahan di kawasan kota yang tidak terdapat aktivitas diatasnya yang disebabkan oleh beberapa faktor, belum munculnya aktivitas baru pada lahan yang ditinggalkan oleh aktivitas sebelumnya dan tidak berkembangnya aktivitas yang pernah ada sebelumnya. Pemilik lahan membutuhkan waktu untuk penyesuaian aktivitas lahan terkait ketersediaan modal, dan lamanya waktu tersebut menyebabkan munculnya lahan tidak termanfaatkan. Lahan tidak termanfaatkan meru-pakan lahan yang memiliki dasar penguasaan, dapat berupa lahan terbangun maupun tidak terbangun namun kurang dimanfaatkan oleh pihak pemilik sesuai dengan sifat dan tujuan rencana tata ruang kawasan tersebut.

Salah satu lahan yang kurang termanfaatkan dengan optimal adalah Lahan di Jalan Raya Meruyung Kota Depok. Lahan ini merupakan lahan kosong milik PT Bangun Citra Permata Prima. Lahan ini terletak di daerah meruyung, Kecamatan Limo Kota depok dan berada pada kawasan komersial. Lingkungan disekitar objek penelitian merupakan kawasan perdagangan dan jasa serta perumahan kepadatan sedang. Selain itu, lokasi ini dekat dengan Mall Cinere dan Masjid Kubah Emas Dian AlMahri serta gedung perkantoran di kawasan Cinere. Namun saat ini lahan masih dalam keada-an kosong tanpa ada aktivitas diatasnya. Berdasarkan hal tersebut, perlu dilakukan penilaian terhadap gedung tersebut agar tidak salah dalam membuat keputusan. Maka itu dilakukan analisis dengan metode Highest and Best Use untuk mengetahui penggunanaan tertinggi dan terbaik pada lahan tersebut.

Analisis lahan Jalan Raya Meruyung Kota Depok. menggunakan prinsip dasar penilaian dengan metode Highest and Best Use (HBU). Penilaian adalah proses menentukan nilai suatu properti, sehingga tipe tertentu dari nilai dan kepentingan yang ada bisa diidentifikasi secara jelas dan tegas. Highest and Best Use (HBU) adalah analisis terhadap kegunaan terbaik dan tertinggi dari suatu bidang tanah kosong (Vacant Land), tanah yang dianggap kosong (Land as Vacant) ataupun property dalam pengembangan (Property as Improved). Analisis ini meliputi empat hal pokok yaitu, analisis kelayakan secara fisik (physically feasible), analisis kelayakan secara peraturan (legally permissible), analisis kelayakan secara keuangan (financially feasible), dan analisis produktivitas yang maksimal (maximally productive). Sebuah properti dikatakan telah memenuhi kriteria HBU jika secara fisik dimungkinkan, diijinkan secara peraturan, layak secara finansial, dan dapat memberikan hasil produktivitas yang paling maksimal. 


\section{II.PENELITIAN TERDAHULU}

Akmaluddin dan Utomo[2], menganalisis lahan kosong seluas 1.150 meter $^{2}$ di Jl. Gubeng Raya no. 54 Surabaya untuk dioptimalisasikan menjadi properti komersial dengan metode Highest and Best Use (HBU). Alternatif yang dipilih yaitu hotel, apartemen, perkantoran dan pertokoan. Produktivitas maksimum yang menghasilkan nilai lahan tertinggi yaitu alternatif properti hotel dengan nilai $\mathrm{Rp} 67.069 .980,31 / \mathrm{m}^{2}$.

Rasyid dan Utomo [3], menganalisis lahan bekas SPBU di Jl. Biliton Surabaya dengan prinsip Highest and Best Use (HBU). Pemilihan alternatif dilakukan dengan cara penyebaran kuesioner, dan didapat alternatif yaitu pertokoan, perkantoran dan pujasera. Kesimpulan dari penelitian ini adalah pertokoan menghasilkan nilai lahan tertinggi yaitu $\mathrm{Rp} 16.457 .465 / \mathrm{m}^{2}$ dan memiliki produktifitas maksimum sebesar $65 \%$.

Mubayyinah dan Utomo [4], menganalisis lahan " $X$ " yang berlokasi di Jalan Raya Dr.Sutomo no.79-81 mempunyai luas $820 \mathrm{~m}^{2}$. Alternatif properti komersial yang digunakan yaitu apartemen, hotel, perkantoran dan pertokoan. Kesimpulan dari penelitian ini didapat alternatif hotel sebagai penggunaan lahan terbaik yang memiliki nilai lahan tertinggi yaitu sebesar Rp $13.148 .307 / \mathrm{m}^{2}$.

Anggarwati dan Utomo [5], menganalisis lahan kawasan komersial Perumahan Citra Raya Surabaya. Alternatif properti komersial yang digunakan adalah kantor, hotel dan kantor dengan ruang serbaguna. Kesimpulan dari penelitian ini didapatkan alternatif kantor sebagai penggunaan lahan tertinggi dan terbaik dengan nilai lahan sebesar $\mathrm{Rp} 27.984 .580,59 / \mathrm{m}^{2}$ dengan peningkatan prosentase produktivitas sebesar 74,9\%.

Faradiany dan Utomo [6], menganalisis lahan kosong di Jemur Gayungan II Surabaya. Alternatif properti komersial yang digunakan berupa apartemen, hotel dan perkantoran. Kesimpulan dari penelitian ini didapatkan alternatif hotel sebagai penggunaan lahan terbaik yang memiliki nilai lahan tertinggi yaitu sebesar $\mathrm{Rp} 9.772 .718 / \mathrm{m}^{2}$ dengan prodiktivitas meningkat sebesar $486 \%$.

Utami dan Utomo [7], menganalisis lahan kosong di kawasan wisata Ubud. Alternatif properti komersial yang digunakan menggunakan 3 alternatif mix used villa dan spa center, dimana alternatif tersebut dijadikan satu properti komersial dengan prosentase penggunaan yang telah ditentukan. Hasil yang didapatkan adalah penggunaan alternatif 1 mix used antara villa $60 \%$ dan spa center $40 \%$ dengan produktivitas sebesar $829 \%$ dan nilai lahan yang didapatkan adalah $\mathrm{Rp} 10.263 .207 / \mathrm{m}^{2}$.

Aziz dan Utomo [8], menganalisis lahan Gedung Serbaguna Purnama di Jl. R.A. Kartini Bangkalan. Alternatif properti komersial yang digunakan berupa supermarket, hotel, dan kolam renang. Hasil yang diperoleh yaitu hotel merupakan alternatif penggunaan tertinggi dengan nilai lahan sebesar $\mathrm{Rp} 4.086 .635 / \mathrm{m}^{2}$ dengan produktifitas maksimum sebesar $253 \%$

Mustika dan Utomo[9], menganalisis revitalisasi Pasar Gubeng Masjid Surabaya. Alternatif komersial single use yang digunakan adalah revitalisasi pasar, sedangkan untuk multi use adalah pasar dengan pusat perbelanjaan dan pasar dengan perkantoran dimana prosentase pasar $40 \%$ dan $60 \%$ sisanya untuk pusat perbelanjaan dan perkantoran. Dari hasil penelitian didapatkan alternatif yang menghasilkan nilai lahan tertinggi dan produktivitas maksimum adalah alternatif pengembangan mix use pasar dengan pusat perbelanjaan.. Nilai lahan yang didapatkan $\mathrm{Rp} 46.946 .524 / \mathrm{m}^{2}$ dengan produktivitas meningkat sebesar $312 \%$.

Herradiyanti dan Utomo[10], menganalisis lahan Pasar Turi Lama Surabaya. Alternatif komersial yang digunakan adalah pertokoan, rumah toko, pasar tradisional dan perkantoran. Dari hasil penelitian didapatkan alternatif pertokoan yang menghasilkan nilai lahan tertinggi sebesar Rp 27.994.695/ $\mathrm{m}^{2}$ dengan produktivitas maksimum sebesar $124 \%$.

\section{METODOLOGI}

Penilaian yang merupakan terjemahan dari kata appraisal /valuation adalah suatu proses pekerjaan yang dilakukan seorang penilai dalam memberikan suatu estimasi dan pendapat (opini) tentang nilai ekonomis suatu property baik berwujud maupun tidak berwujud berdasarkan analisis terhadap faktafakta yang obyektif dan relevan dengan menggunakan metode penilaian tertentu serta mengacu kepada prinsip-prinsip penilaian yang berlaku.

Properti adalah konsep hukum yang mencakup kepentingan, hak dan manfaat yang berkaitan dengan suatu kepemilikan. Properti terdiri atas hak kepemilikan, yang memberikan hak kepada pemilik untuk suatu kepentingan tertentu (specific interest) atau sejumlah kepentingan atas apa yang dimilikinya. Oleh karena itu, kita wajib memperhatikan konsep hukum dari properti yang meliputi segala sesuatu yang merupakan konsep kepemilikan atau hak dan kepentingan yang bernilai, berbentuk benda atau bukan (corporeal or noncorporeal), berwujud atau tidak berwujud, dapat dilihat atau tidak, yang memiliki nilai tukar atau yang dapat membentuk kekayaan. (KPUP pasal 3.0, 2012) [11]

Untuk menentukan penggunaan tertinggi dan terbaik pada sebidang lahan, maka terdapat empat langkah pengujian yang harus dilakukan. Proses pengujian tersebut yaitu

\section{A. Aspek Legal}

Pada aspek ini terdapat dua jenis analisis yang akan dilakukan, antara lain:

1. Zoning

Analisis peramalan peruntukan lahan yang ditinjau sehingga dapat mengembangkan dan mendatangkan nilai tertinggi.

2. Building Code

Analisis yang dilakukan sesuai persyaratan yang telah ditetapkan oleh pemerintah, yaitu GSB, KDB, KLB, KDH, Tinggi maksimum bangunan.

\section{B. Aspek Fisik}

Metode yang digunakan untuk analisis aspek fisik adalah dengan cara observasi lapangan dan wawancara dengan stakeholder. Pada Aspek fisik ini terdapat beberapa hal yang di analisis, diantaranya:

1. Bentuk Lahan

Hal yang ditinjau meliputi luas lahan dan bentuk lahan. Bentuk dan luas lahan akan mempengaruhi jenis properti yang akan dikembangkan dan akan memberikan nilai yang berbeda. 


\section{Aksesibilitas}

Hal yang ditinjau meliputi kemudahan pada suatu lahan untuk dicapai seperti:

a. Tersedianya sarana transportasi

b. Lalu lintas dan kemacetan

3. Ketersediaan sarana publik

Pada suatu lahan harus didukung juga oleh ketersediaan sarana publik. Semakin baik sarana public yang ada maka lahan tersebut semakin baik penggunaannya. Hal yang ditinjau meliputi :
a. Jalan
b. Listrik
c. Telepon
d. Jaringan PDAM

4. Bentuk preliminary desain dari properti yang direncanakan

\section{Penentuan Alternatif Penggunaan Lahan}

Penentuan alternatif penggunaan lahan dilakukan dengan cara observasi di lapangan yaitu dengan mengamati bangunan di sekitar objek penelitian. Selain itu dilakukan juga wawancara terstruktur dan penyebaran kuisioner kepada stakeholder yang terdiri dari pemilik lahan dan masyarakat sekitar Hal ini dilakukan agar dapat memberikan pilihan alternatif yang telah spesifik kepada responden sehingga konsistensi jawaban para responden akan lebih baik. Selain itu pemilihan alternatif juga harus mempertimbangkan kesesuaian bangunan eksisting dengan bangunanan alternatif yang direncanakan. Kemudian dari hasil tersebut diperoleh 4 alternatif dengan suara terbanyak dari koresponden kuisioner yang telah disesuaikan dengan bangunan eksisting.

Setelah diperoleh alternatif bangunan, langkah selanjutnya adalah membuat basic design untuk masing-masing alternatif lalu menguji alternatif yang didapat dengan syarat Highest and Best Use (HBU) yaitu aspek finansial, dan produktivitas maksimum.

\section{D.Aspek Finansial}

Alternatif yang telah melewati tiga tahapan analisis diatas lalu dilakukan analisis kelayakan finansialnya. Pengujian kelayakan finansial dilakukan melalui analisis aliran kas, yaitu biaya investasi, pendapatan dan pengeluaran. Pendapatan dan pengeluaran diprediksi akan mengalami peningkatan dengan prosentase perubahan tertentu setiap jangka waktu tertentu. Nilai yang berbeda-beda setiap periode tertentu kemudian di discounted faktorkan menjadi nilai sekarang dan menghasilkan Net Present Value (NPV). Nilai MARR yang digunakan adalah nilai rata-rata tingkat suku bunga bank \pm nilai resiko yang diterima. Besarnya nilai resiko diasumsikan sama dengan tingkat suku bunga bank. Alternatif properti dinyatakan layak jika NPV > 0 .

Pada aspek finansial terdapat 5 jenis analisis yang dilakukan, yaitu:

1. Biaya Investasi

Biaya investasi yaitu penempatan sejumlah dana atau barang dalam jangka waktu tertentu. Adapun perincian perhitungan biaya investasi antara lain:

a. Biaya Tanah

Biaya tanah merupakan harga tanah standar per $\mathrm{m}^{2}$ dari suatu lahan. Data ini didapat dari perbandingan harga tanah sejenis. b. Biaya Investasi

Biaya investasi diperoleh dari penjumlahan biaya tanah, nilai bangunan dan biaya renovasi.

\section{Pendapatan}

Pendapatan diperoleh dari hasil penjualan atau penyewaan, service charge dan pendapatan tambahan tergantung masing-masing alternative. Service charge merupakan biaya untuk perawatan gedung, fasilitas umum, kebersihan dan keamanan yang secara rutin harus dikeluarkan oleh si pemilik atau penyewa. Biaya ini dihitung per $\mathrm{m}^{2}$ bangunan yang merupakan pendapatan pengelola.

3. Pengeluaran

Pengeluaran untuk tiap jenis altenatif bangunan terdiri dari biaya operasional, biaya pemeliharaan dan penggantian. Biaya operasional meliputi biaya listrik, biaya air, dan gaji pegawai.

4. Aliran Kas

Proses keluar masuknya uang atau aset perusahaan. Dimana proses tersebut harus tercatat dengan jelas.

\section{Net Present Value (NPV)}

Menganalisis selisih antara benefit (penerimaan) dengan cost (pengeluaran) yang telah di-present value kan. Tingkat bunga yang dipergunakan untuk mendiskonkan selisih aliran kas yang masuk dan keluar diperoleh dengan melihat tingkat bunga pinjaman jangka panjang yang berlaku di bank atau dengan menggunakan tingkat bunga pinjaman yang harus dibayar pemilik proyek jika ada. Apabila NPV > 0 , maka proyek dikatakan layak, sedangkan sebaliknya jika NPV < 0, maka proyek dikatakan tidak layak.

\section{E. Penetapan Penggunaan Terbaik}

Alternatif yang mempunyai nilai NPV $>0$ dan dikatakan layak kemudian dicari nilai lahan dengan perumusan

Nilai Lahan $/ m^{2}=\frac{\text { Nilai Properti }- \text { Nilai Bangunan }}{\text { Total Luas Lahan }}$

Nilai properti diasumsikan dari total pendapatan dan pengeluaran selama masa investasi yang telah di discounted faktorkan menjadi nilai sekarang. Sedangkan nilai bangunan diasumsikan sebesar nilai investasi bangunan. Properti komersial terbaik untuk lahan di Jalan Raya Meruyung Kota Depok dipilih dari hasil analisis Highest and Best Use (HBU). Alternatif properti terbaik adalah alternatif yang memiliki nilai lahan tertinggi dan merupakan alternatif yang memiliki produktivitas maksimum.

\section{ANALISIS DAN HASIL}

\section{A. Gambaran Umum Objek Yang Diteliti}

Lahan yang digunakan sebagai objek dalam penelitian ini merupakan lahan milik PT. Bangun Citra Permata Prima. Lahan ini terletak di Jalan Raya Meruyung, kecamatan Limo, Kota Depok. Lahan tersebut memiliki luas $14376 \mathrm{~m}^{2}$. Lahan objek berupa lahan kosong yang saat ini digunakan sebagai perkebunan.

Lahan objek penelitian berbatasan langsung dengan Jalan Raya Meruyung yang merupakan jalur arteri sekunder yang menghubungkan Jalan Raya Limp, Jalan Raya Cinere dan Jalan Sawangan sehingga akses menuju lokasi mudah. Terdapat transportasi umum yang melewati sekitar lokasi penelitian, 
diantaranya angkutan kota, taksi dan ojek. Lingkungan disekitar objek penelitian merupakan kawasan perdagangan dan jasa serta perumahan kepadatan sedang. Selain itu, lokasi ini dekat dengan Mall Cinere dan Masjid Kubah Emas Dian Al-Mahri. Selain itu, objek penelitian juga dekat dengan gedung perkantoran di kawasan Cinere.

Pada analisis Highest and Best Use yang akan dilakukan, diperlukan data - data yang menunjang seperti peraturan yang berlaku dan telah ditetapkan oleh pemerintah yaitu zoning atau peruntukkan lahan, selain itu juga harus diperhatikan data pendukung lahan dan bangunan tersebut.

\section{B. Analisis Aspek Legal}

Berdasarkan peraturan Peraturan Daerah No. 1 Tahun 2015 tentang Rencana Tata Ruang Wilayah Kota Depok Tahun 20122032 [12]dan Peraturan Walikota Depok No. 15 Tahun 2013 tentang Penetapan dan Persyaratan Jarak Bebas Bangunan Serta Pemanfaatan pada Daerah Sempadan dan analisis aspek legal diatas yaitu objek penelitian yang memiliki lahan seluas 14376 $\mathrm{m}^{2}$ dengan luas dasar bangunan $8626 \mathrm{~m}^{2}$, luas lantai bangunan $86256 \mathrm{~m}^{2}$ yang terdiri dari 10 lantai, KLB 6, KDB maksimum $60 \%$, dan KDH minimum 20\%. Sehingga dapat disimpulkan penggunaan lahan ini secara aspek legal diijinkan dan lahan ini berpotensi untuk dikembangkan sebagai bangunan komersial dan permukiman.

\section{Aspek Fisik}

Setelah melakukan analisis aspek legal, syarat kedua yang harus dilakukan adalah melakukan analisis aspek fisik. Dalam menentukan kelayakan aspek fisik diperlukan beberapa kriteria yang harus dipenuhi, antara lain: lokasi lahan, ukuran dan bentuk lahan, aksesibilitas lahan dan utilitas.

\section{Analisis Lokasi Lahan}

Berdasarkan data, lahan objek penelitian yang terletak di Jalan Raya Meruyung, Kota Depok mempunyai lokasi yang cocok untuk properti komersial. Lingkungan disekitar objek penelitian merupakan kawasan perdagangan dan jasa serta permukiman. Berikut merupakan lokasi objek penelitian pada

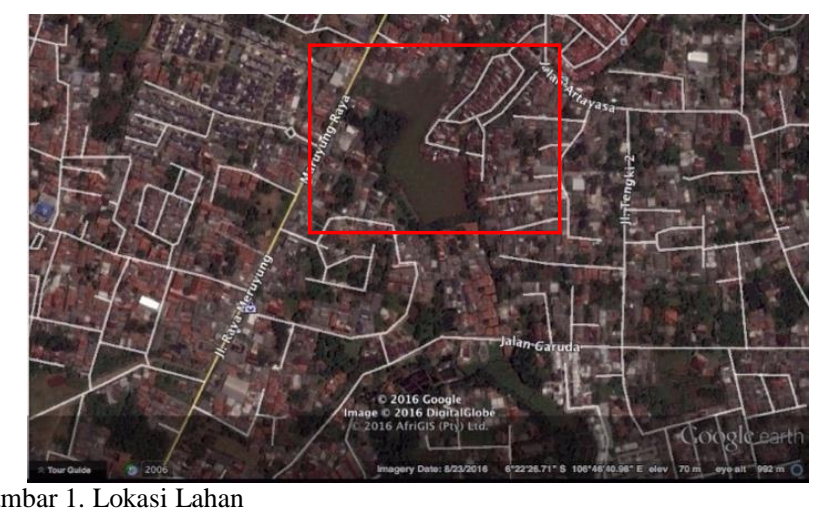

\section{Bentuk dan Ukuran Lahan}

Berdasarkan data, lahan ini memiliki luasan sebesar $14376 \mathrm{~m}^{2}$. Luasan lahan objek penelitian yang cukup luas menjadikan lahan ini cocok digunakan sebagai bangunan yang memiliki kebutuhan ruang yang luas. Berikut bentuk lahan objek penelitian

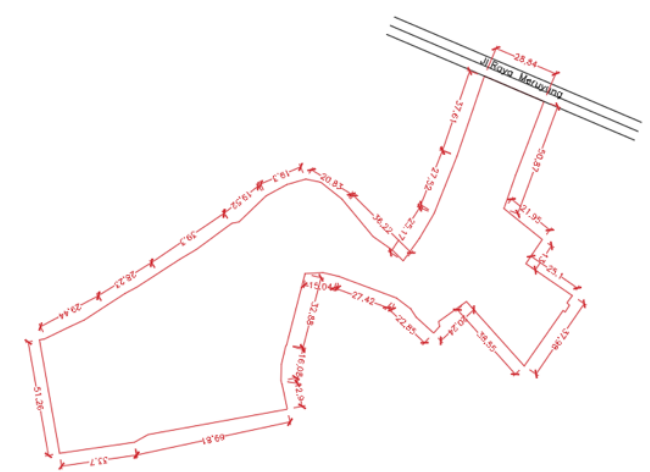

Gambar 2. Bentuk Lahan

\section{Aksesibilitas Lahan}

Berdasarkan data hasil pengamatan, aksesibilitas lahan objek penelitian ini sudah baik ditinjau dari ketersediaan akses keluar masuk dan transportasi umum seperti angkutan kota dan taksi. Selain itu, lahan terletak di Jalan Raya Meruyung yang merupakan jalan arteri sekunder penghubung daerah cinere dan sawangan

4. Utilitas

Lahan objek penelitian ini telah memiliki kelengkapan utilitas kota yang baik. Utilitas yang tersedia seperti saluran listrik, telepon dan air bersih.

5. Pemilihan Alternatif

Pemilihan alternatif dipilih berdasarkan peruntukkan lahan, pengamatan bangunan disekitar lokasi objek penelitian, wawancara dan penyebaran kuisioner pada stakeholder terkait yaitu PT. Bangun Citra Permata Prima sebagai pemilik lahan, pengelola mall cinere yang terletak tidak jauh dari lokasi lahan penelitian. Objek penelitian merupakan lahan kosong di Jalan Raya Meruyung seluas $14376 \mathrm{~m}^{2}$. Alternatif properti yang terdapat di kuisioner didapatkan dari peruntukkan lahan (zoning) yang sesuai dengan peraturan setempat dan pengamatan langsung pada daerah sekitar lahan objek penelitian dengan memperhatikan jenis-jenis properti yang telah dibangun sebelumnya. Pengisian kuisioner oleh stakeholder dapat dilihat pada lampiran 1 dan 2. Berikut adalah hasil kuisioner pemilihan alternatif.

Berdasarkan hasil survey tersebut didapatkan alternatif property berupa:

1. Hotel

2. Kantor dan Aula Serbaguna

3. Rumah Toko (Ruko) dan Perumahan

\section{Aspek Finansial}

Setelah melewati tahapan analisis aspek legal dan aspek fisik, lalu dilakukan analisis finansial. Analisis finansial meliputi biaya investasi, pendapatan dan pengeluaran

\section{Perencanaan Biaya Investasi}

Dalam perencanaan biaya investasi terdiri dari biaya tanah dan biaya bangunan. Perhitungan harga tanah per $\mathrm{m} 2$ didapat berdasarkan pendekatan data pasar dan penyesuaian. Sedangkan untuk biaya bangunan didapat berdasarkan analisis unit terpasang. Berdasarkan peraturan Menteri Pekerjaan Umum nomor 45/PRT/ M/2007 Tentang Pedoman Teknis Pembangunan Bangunan Gedung Negara, besarnya biaya kontruksi fisik maksimum untuk pekerjaan standar dihitung dari hasil perkalian total luas bangunan gedung negara dengan 
standar harga satuan per- $\mathrm{m}^{2}$ yang berlaku. Untuk pekerjaan standar bangunan negara dan rumah negara sebagai pedoman penyusunan anggaran pembangunan dapat berpedoman pada prosentase komponen-komponen pekerjaan.

Pembobotan dari standar pemerintah kemudian diolah dan disesuaikan dengan desain alternatif hingga prosentase biaya sebesar $100 \%$.

Tabel 1.

Perencanaan Biaya Investasi

\begin{tabular}{cccc}
\hline \hline Uraian & Hotel & $\begin{array}{c}\text { Perkantoran dan } \\
\text { Aula Serbaguna }\end{array}$ & $\begin{array}{c}\text { Ruko dan } \\
\text { Perumahan }\end{array}$ \\
\hline $\begin{array}{c}\text { Biaya } \\
\text { Tanah }\end{array}$ & Rp70,514,280,000 & Rp70,514,280,000 & Rp70,514,280,000 \\
$\begin{array}{c}\text { Biaya } \\
\text { Bangunan } \\
\text { Total }\end{array}$ & Rp66,570,761,944 & Rp165,265,947,153 & Rp35,178,671,411 \\
\hline \hline
\end{tabular}

2. Perencanaan Pendapatan

Perencanaan pendapatan untuk alternative bangunan berasal dari penyewaan atau penjualan dan service charge

Tabel 2.

Perencanaan Pendapatan

\begin{tabular}{cccc}
\hline \hline Uraian & Hotel & $\begin{array}{c}\text { Perkantoran dan } \\
\text { Aula Serbaguna }\end{array}$ & Ruko dan Perumahan \\
\hline 2018 & Rp24,441,570,000 & Rp43,937,160,000 & Rp19,523,552,000 \\
2019 & Rp24,441,570,000 & Rp43,937,160,000 & Rp31,266,976,000 \\
2020 & Rp24,441,570,000 & Rp43,937,160,000 & Rp34,844,960,000 \\
2021 & Rp24,441,570,000 & Rp43,937,160,000 & Rp444,960,000 \\
2022 & Rp24,441,570,000 & Rp43,937,160,000 & Rp444,960,000 \\
2023 & Rp25,663,648,500 & Rp46,134,018,000 & - \\
\hline \hline
\end{tabular}

3. Perencanaan Pengeluaran

Perencanaan pengeluaran terdiri dari biaya operasional dan biaya pemeliharaan.

a. Biaya Operasional

Biaya operasional terdiri dari biaya pengunaan listrik, biaya penggunaan air dan gaji pegawai.

b. Biaya Pemeliharaan

Biaya pemeliharaan yang dikeluarkan bertujuan agar kondisi gedung dan utilitas tetap dalam kondisi baik. Biaya pemeliharaan diasumsikan sebesar $15 \%$ dari service charge (juwana, 2005) [13].

Tabel 3

Perencanaan Pengeluaran

\begin{tabular}{cccc}
\hline Uraian & Hotel & $\begin{array}{c}\text { Perkantoran dan } \\
\text { Aula Serbaguna }\end{array}$ & Ruko dan Perumahan \\
\hline 2018 & Rp7,890,718,759 & Rp6,710,288,112 & Rp119,845,440 \\
2019 & Rp8,541,833,243 & Rp7,486,666,677 & Rp269,709,574 \\
2020 & Rp8,855,901,815 & Rp7,737,115,299 & Rp457,048,808 \\
2021 & Rp9,100,193,809 & Rp7,878,683,821 & Rp475,566,695 \\
2022 & Rp9,330,040,379 & Rp7,997,711,553 & Rp479,400,341 \\
2023 & Rp9,696,213,348 & Rp8,329,464,418 & - \\
\hline \hline
\end{tabular}

\section{Analisis Arus Kas}

Analisis arus kas menggunakan metode NPV (Net Present Value) yang merupakan pengurangan dari pendapatan dengan pengeluaran tiap tahunnya selama masa investasi hingga didapatkan aliran kas bersih (Net Cash Flow). Net cash flow kemudian disesuaikan dengan faktor diskon tingkat pengembalian yang diharapkan. Apabila NPV >0, maka proyek dikatakan layak, sedangkan sebaliknya jika NPV $<0$, maka proyek dikatakan tidak layak.

Besarnya nilai resiko diasumsikan sama dengan tingkat suku bunga bank. Sehingga nilai MARR yang diperoleh dari tingkat suku bunga \pm resiko dimana resiko diasumsikan sebesar tingkat suku bunga, sehingga MARR sebesar $11,4 \%$. Masa investasi yang direncanakan adalah 6 tahun untuk alternative hotel dan perkantoran+Aula serbaguna berdasarkan Siklus Bisnis Properti Bank Indonesia, sedangkan untuk alternative ruko dan perumahan direncanakan selama 3 tahun. Perhitungan arus kas untuk setiap alternative disajikan pada lampiran. Semua jenis alternative dinyatakan lulus uji dalam kelayakan finansial sesuai dengan persyaratan NPV bernilai positif.

Tabel 4.

Kelayakan Finansial

\begin{tabular}{cccc}
\hline \hline \multirow{2}{*}{ Uraian } & \multicolumn{3}{c}{ Alternatif } \\
\cline { 2 - 4 } & Hotel & $\begin{array}{c}\text { Perkantoran + Aula } \\
\text { Serbaguna }\end{array}$ & Ruko + Perumahan \\
\hline Investasi & $\mathrm{Rp} 137,085,041,944$ & $\mathrm{Rp} 235,780,227,153$ & $\mathrm{Rp} 105,836,711,411$ \\
Pendapatan & $\mathrm{Rp} 147,871,498,500$ & $\mathrm{Rp} 265,819,818,000$ & $\mathrm{Rp} 86,721,248,000$ \\
Pengeluaran & $\mathrm{Rp} 53,414,901,353$ & $\mathrm{Rp} 46,139,929,880$ & $\mathrm{Rp} 1,640,047,068$ \\
NPV & $\mathrm{Rp} 2,267,793,915$ & $\mathrm{Rp} 90,847,496,470$ & - -Rp38,359,147,115 \\
Hasil & Layak & Layak & Tidak Layak \\
\hline \hline
\end{tabular}

\section{Analisis Arus Kas}

Alternatif-alternatif yang telah lulus pengujian aspek legal, fisik dan finansial akan dicari nilai lahannya melalui uji produktivitas maksimum. Produktivitas lahan merupakan peningkatan nilai lahan per $\mathrm{m}^{2}$ sebagai akibat dari aktivitas diatasnya. Nilai lahan per $\mathrm{m}^{2}$ diperoleh dengan menggunakan metode penyisaan tanah yaitu selisih nilai property dengan nilai bangunan dibagi luas total lahan. Nilai bangunan diperoleh berdasarkan hasil perhitungan biaya investasi bangunan. Sedangkan nilai property diperoleh dari perhitungan terminal value. Terminal value didapatkan dari pendapatan dikurangi dengan pengeluaran diakhir masa investasi dibagi dengan cap rate. Cap rate direncanakan sebesar $11,4 \%$. sehingga dari terminal value tersebut diperoleh nilai property yang kemudian digunakan untuk menghitung produktivitas maksimum.

Tabel 5.

Produktivitas Maksimum

\begin{tabular}{ccc}
\hline \hline \multirow{2}{*}{ Uraian } & \multicolumn{2}{c}{ Alternatif } \\
\cline { 2 - 3 } & Hotel & $\begin{array}{c}\text { Perkantoran + Aula } \\
\text { Serbaguna }\end{array}$ \\
\hline Nilai Properti & Rp140,065,220,627 & Rp331,618,891,072 \\
Nilai Investasi & Rp137,085,041,944 & Rp235,780,227,153 \\
Biaya Tanah & Rp70,514,280,000 & Rp70,514,280,000 \\
Nilai Bangunan & Rp66,570,761,944 & Rp165,265,947,153 \\
Nilai Lahan & Rp73,494,458,684 & Rp166,352,943,919 \\
Nilai Lahan/m2 & Rp5,112,302 & Rp11,571,574 \\
Produktivitas & $4 \%$ & $136 \%$ \\
\hline \hline
\end{tabular}

\section{KESIMPULAN/RINGKASAN}

Penelitian ini bertujuan untuk menentukan bangunan properti komersial tertinggi dan terbaik pada lahan di Jalan Raya Meruyung. Dari hasil analisis legal dan fisik, terpilih 3 
alternatif property yaitu hotel, perkantoran dan aula serbaguna, serta ruko dan perumahan untuk di analisis kelayakan finansial.

Dari hasil analisis Highest and Best Use yang telah dilakukan Perkantoran dan Aula Serbaguna memiliki nilai lahan tertinggi yaitu sebesar $\mathrm{Rp} 11.571 .574$ dengan produktivitas tertinggi sebesar $136 \%$. Jadi dapat disimpulkan bahwa peruntukan lahan untuk pengembangan properti komersial Perkantoran dan Aula Serbaguna merupakan alternatif penggunaan terbaik untuk lahan di Jalan Raya Meruyung kota Depok.

\section{DAFTAR PUSTAKA}

[1] Prasetya. 2012." Identifikasi Pola Perubahan Fungsi Kawasan Seampadan Kali Cisadane Menjadi Kawasan Budidaya Koridor Neglasari-Kecamatan Neglasari Kota Tangerang". Penelitian Program Studi Planologi. Jakarta : Universitas Esa Unggul

[2] Akmaluddin, A. dan Utomo, C. 2013.Analisis Highest And Best Used Jl. Raya Gubeng No. 54 Surabaya. Jurnal Jurusan Teknik Sipil ITS Vol. 2 No. 1 : 2301-9271 C6-C10.

[3] Rasyid,T.D.A. dan Utomo, C .2013. Analisis Highest and best use (HBU) pada lahan bekas SPBU Biliton. Jurnal Jurusan Teknik Sipil ITS Vol. 2 No. 2 : 2301-9271 D181-D185.

[4] Mubayyinah, M dan Utomo, C. 2012. "Analisis Highest and Best

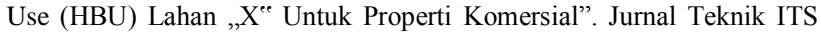
Vol. 1, No. 1, hal. D16-D19.

[5] Anggarwati, B dan Utomo, C. 2013. Analisis Penggunaan Lahan Kawasan Komersial Perumahan Citra Raya Surabaya dengan Metode Highest and Best Use. Surabaya: Jurnal Teknik ITS 2 No.2, D39-D41.

[6] Faradiany, F.V. dan Utomo, C. 2014. Analisis Highest and Best Use Pada Lahan Kosong Di Jemur Gayungan II Surabaya. Surabaya : Jurnal Teknik ITS 3 (2), C61-63.

[7] Utami, N.P.K. dan Utomo, C. 2015. Analisis Highest adn Best Use pada Lahan Kosong di Kawasan Wisata Ubud. Surabaya: Jurnal Teknik ITS Vol. 4, No. 1, C41-C44.

[8] Aziz, C.N. dan Utomo, C. 2015. Analisis Highest ad Best Use pada Lahan Gedung Serbaguna Purnama di Jl. R.A. Kartini Bangkalan. Surabaya: Jurnal Teknik ITS Vol. 4, No. 1, D51-D53

[9] Mustika, M. S. Dan Utomo, C. 2016. Analisis Alternatif Revitalisasi Pasar Gubeng Masjid dengan Metode Highest and Best Use. Surabaya: Jurnal Teknik ITS Vol. 5, No. 2, C75-C77

[10] Herradiyanti, M. Dan Utomo, C. 2016. Analisis Penggunaan Tertinggi dan Terbaik (Highest and Best Use Analysis) pada Lahan Pasar Turi Lama. Surabaya: Jurnal Teknik ITS Vol. 5, No. 2, D172-D175

[11] Komite Penyusunan Standar Penilai Indonesia (KPSPI) dan Masyarakat Profesi Penilai Indonesia (MAPPI). 2012. Standar Penilaian Indonesia (SPI).

[12] Pemerintah Kota Depok. 2015. "Peraturan Daerah Kota Depok No. 1 Tahun 2015 tentang Rencana Tata Ruang Wilayah Kota Depok”. Depok.

[13] Juwana, J. S. 2005. "Panduan Sistem Bangunan Tinggi Untuk Arsitek dan Praktisi Bangunan". Jakarta : Erlangga. 